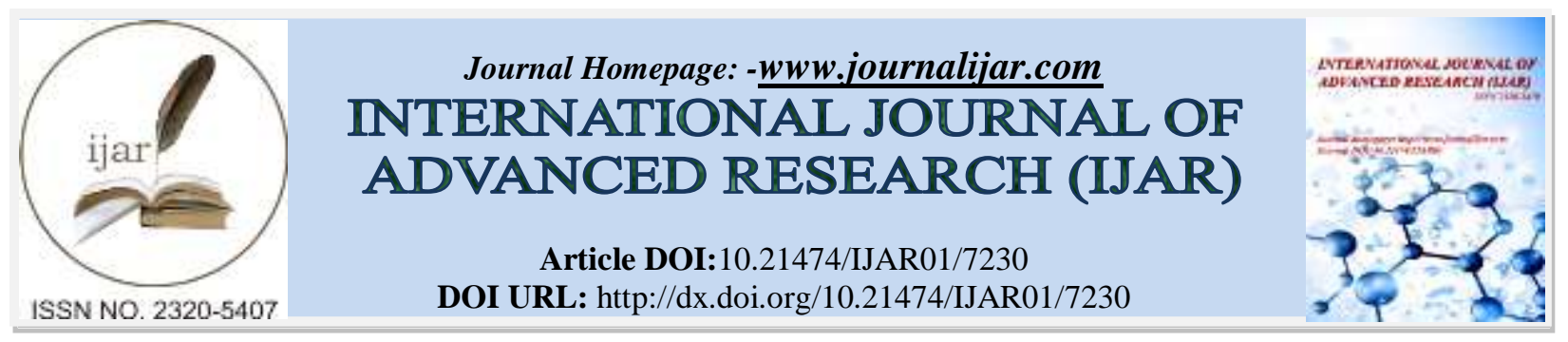

RESEARCH ARTICLE

\title{
ADSORPTIVE STRIPPING VOLTAMMETRIC DETERMINATION OF ULTRA TRACE COBALT WITH ALIZARIN RED S MODIFIED CARBON PASTE ELECTRODE.
}

\author{
Ahmed. A. Gahlan. \\ Chemistry Department, Faculty of Science, Al-Azhar University, Assiut branch, 71524, Assiut, Egypt.
}

\section{Manuscript Info}

Manuscript History

Received: 08 April 2018

Final Accepted: 10 May 2018

Published: June 2018

Keywords:-

Adsorptive Stripping Voltammetry,

Cobalt, Alizarin Red S, Trace

Electroanalysis, and Determination.

\section{Abstract}

A very sensitive and selective square wave cathodic adsorptive stripping (SWCAS) voltammetric method at modified carbon paste electrode (CPE) for determination of Cobalt(II) has been developed and evaluated. Square wave Cathodic Adsorptive Stripping Voltammetric (SWCASV) mechanism is proposed to interpret the amplified sensitivity. The procedure is based on the interfacial preconcentration of Cobalt (II) ion on Alizarin Red S through a surface coordination effect. The effect of various parameters such as medium, $\mathrm{pH}$, accumulation potential, scan rate, accumulation time and ionic strength were tested to optimize the conditions for the determination of Cobalt(II) ion. The adsorbed form is reduced irreversible at optimal conditions viz; $0.15 \mathrm{M}$ Phosphate buffer ( $\mathrm{pH} 9.5)$. Linear concentration range $2 \times 10^{-12}-6 \times 10^{-11} \mathrm{M}(0.00012-$ $0.00354 \mathrm{ng} / \mathrm{mL}$ ) at $60 \mathrm{~s}$, can be determined successfully. The interferences of some common foreign species and some metal ions were studied.

The high sensitivity and selectivity of this method were demonstrated by determination of cobalt in human hair and water samples.

Copy Right, IJAR, 2018,. All rights reserved.

\section{Introduction:-}

Cobalt (Co) as an important element in environment is an essential element in biological compounds like vitamin $\mathrm{B}_{12}$ and some metalloprotein. Since the concentration of cobalt is extremely low in various natural samples, a sufficient and selective analytical procedure for the reliable determination of cobalt in natural sample would be of great interest. The most common technique for determination low concentration of cobalt is application of Graphite furnace atomic absorption (GFAAS) after a preconcentration step. This technique has difficulties achieving the sensitivity required for the determination of the low level of cobalt in natural water and includes a high risk of sample contamination or loss of analyte during the several sample preparation steps involved.

Amongst the various analytical methods, adsorptive stripping voltammetry (AdSV) technique [1] is becoming a widely accepted analytical tool, as a high sensitive and economic method in determination of some ions in water and in addition the metal preconcentration is performed in this case is performed in situ. The preconcentration step used in AdSV involves adsorption of a complex with a specific chelating agent on a hanging mercury drop electrode (HMDE). The sensible combination of adsorptive stripping voltammetry (AdSV) and catalytic process produced a remarkably sensitive method named catalytic adsorptive stripping voltammetry (CAdSV) suitable for ultra trace measurement of certain metals [2]. Several stripping voltammetry methods were reported for trace determination of cobalt [3-7]. 
Many of the adsorptive stripping voltammetric (AdSV) approach features such as sensitivity, selectivity, simplicity and versatility attributed to the combination of an effective preconcentartion step based on non-electrolytic adsorptive accumulation process with an advanced measurement procedures such as DP or SW [8-12]. Unlike conventional stripping approaches (anodic and cathodic stripping voltammetry), which are based on an electrolytic nature of preconcentration step, AdSV approach in contrast is based on adsorptive accumulation of the analyte on the electrode at open circuit with no charge transferred. Consequently, for a wide range of surfaceactive organic and inorganic species, which cannot be preconcentrated electrolytically, the adsorption approach allows these analytes to be interfacially accumulated on the electrode and hence analysed. There have been many reviews devoted to emphasize and illustrate the wide spectrum and scope of AdSV applications and potentialities in the analysis of metal ions [13,14] organic analytes [15] and pharmaceutical drugs and biomedical compounds [16, 17].

This work presents a catalytic adsorptive stripping voltammetry method for the determination of Cobalt(II), using (ARS) as a ligand in presence of $0.15 \mathrm{M}$ Britton-Robinson universal buffer. This system provides the lowest detection limit $2 \times 10^{-13} \mathrm{M}$ ever reported for determination of $\mathrm{Co}(\mathrm{II})$. Furthermore, we introduce a new method as a very sensitive technique for determination of $10^{-10} \mathrm{M}$ concentration of $\mathrm{Co}(\mathrm{II})$ in some real samples.<smiles>O=C1c2ccccc2C(=O)c2c1cc(S(=O)(=O)O)c(O)c2O</smiles>

Structure of Alizarin Red S: 1,2-dihydroxy-9,10-anthraquinone-3- sulfonate (ARS)

\section{Experimental:-}

Apparatus:-

All voltammeteric experiments were performed with EG\&G Princeton Applied Research (PAR Princeton, NJ, USA) Model 273 A potentiostat, controlled by the model 270/250 electrochemical software version 4.30. A three-electrode cell was employed incorporating a hand-make working carbon paste electrode that prepared as previously mentioned [18], an $\mathrm{Ag} / \mathrm{AgCl}$ (saturated $\mathrm{KCl}$ ) reference electrode and platinum wire was used as a counter electrode. Mass transport was achieved with a Teflon-coated bar at approximately $400 \mathrm{rpm}$ using a magnetic stirrer (KIKA Labortechinik, Germany). All pH measurements were made with VWR scientific products model 2000 , USA.

\section{Reagents and solutions:-}

All chemical used were either analytical or primary standard grade and were used without further purification. Bi-distilled water and Ethanol were used throughout Standard free sodium hydroxide solution $0.2 \mathrm{M}$; the sodium hydroxide solution was standardized against standard potassium hydrogen phthalate.

The solution of $\mathrm{Co}(\mathrm{II})$ ion (Merck, BDH) as nitrate was prepared and titrated complexometrically by EDTA [19]. The (ARS) solution, with a concentration of $1 \times 10^{-4} \mathrm{~mol} / \mathrm{L}$, was prepared for the electrode modification.

\section{Methods:-}

\section{Electrode modification:-}

Carbon paste electrode $15 \%$ was prepared by mixing with 4.25 gm of pure carbon with 0.75 gram paraffin oil. This electrode was then immersed in a $1 \times 10^{-4} \mathrm{~mol} / \mathrm{L}$ Alizarin red S (ARS) solution for about 20 seconds to let (ARS) absorb on the electrode surface. The electrode is then ready for the cobalt preconcentration step.

\section{Voltammetric procedure for Co(II) determination:-}

The preconcentration step was performed by immersing the carbon paste electrode in stirring $15 \mathrm{ml}$ sample solution for a given period of time at potential rang from (-0.35) to (-0.6) $\mathrm{V}$ for $\mathrm{Co}$ (II) ion, then stop the stirring and delay period of $15 \mathrm{sec}$ to the stele the solution and decrease the background current, square wave voltammogram was recorded in the potential direction. A renewed (ARS) - carbon paste surface electrode was used for each measurement. 
For determination of Co(II) ion $30 \mu \mathrm{L}, 2 \times 10^{-6} \mathrm{M}$ (containing $117.86 \mathrm{ng} / \mathrm{mL}$ ) of Co(II) metal was added to $15 \mathrm{ml}$ $0.15 \mathrm{M}$ Phosphate buffer $\mathrm{pH}=9.5$. The solution was stirred at 400 ramps at open circuit conditions and the square wave voltammogram was recorded.

The optimum operational parameters selected for the determination of Co(II) by SWCASV using modified CPE illustrated in Table 1.

Table 1:-The optimum operational parameters selected for the determination of Co(II) by SWCASV at modified CPE.

\begin{tabular}{|c|c|}
\hline Parameter & Selected value \\
\hline Accumulation potential & $-0.35 \mathrm{~V}$ \\
Final potential & $-0.6 \mathrm{~V}$ \\
Modulation time & $10 \mathrm{~S}$. \\
Frequency & $50 \mathrm{HZ}$ \\
Scan increment & $2 \mathrm{mV}$ \\
Accumulation time & Various \\
PH & 9.5 \\
Buffer type & $0.15 \mathrm{M}$ Phosphate Buffer \\
\hline
\end{tabular}

\section{Results and Discussion:-}

\section{Voltammetric Response and possible mechanism:-}

The possible mechanism for the formation of the Co(II)-(ARS) complex on the electrode surface [20], the (ARS) molecule can be strongly adsorbed on a carbon paste surface coordinating with the cobalt ion to form a surface complex. The molecular structures of the formed surface $\mathrm{Co}$ (II) complex and its one-electron reduction product the $\mathrm{Co}(\mathrm{I})-(\mathrm{ARS})$ and complex is proposed in Fig(1), based on fact the metal ion has a coordination number of 6 .

The formula for the compound should therefore contain 4 water molecules if the central ion is bonded to only two sites of the ligand molecule.

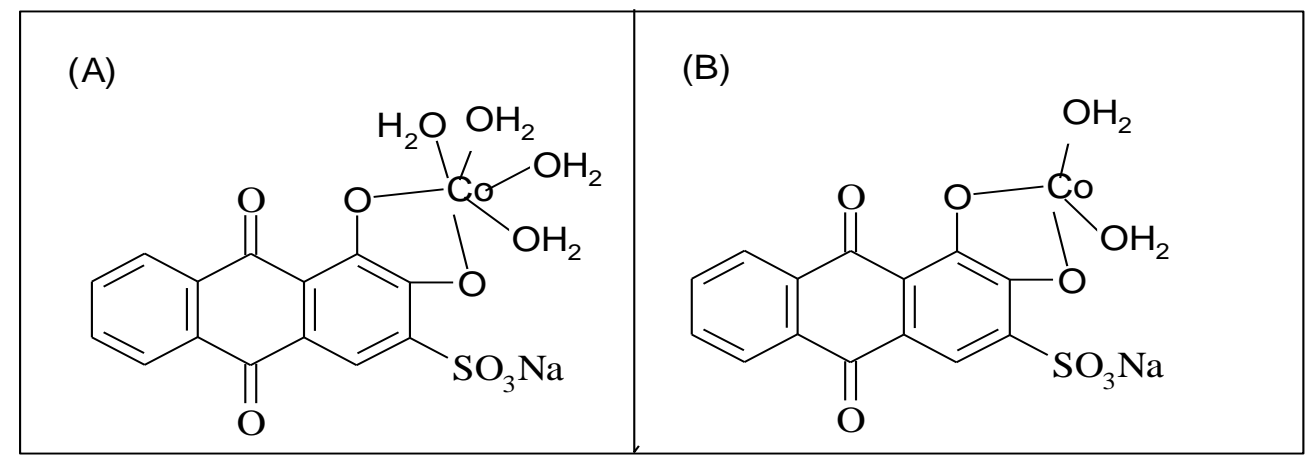

Figure1:-Proposed molecular structures for (A) Co(II) - (ARS) and (B) Co(I)- (ARS) complexes.

The stripping peak near $E_{\max }=\mathbf{- 0 . 5 1 8 V}$ is believed to be the catalytic-adsorptive current associated with the preconcentrated $\mathrm{Co}(\mathrm{I})$ - (ARS) complex.

The possible mechanism for the whole process may be proposed as follows for Co(II)- (ARS) Complex.

Preconcentration step:

$\mathrm{Co}(\mathrm{II})$ (solution) + (ARS) (adsorbed) $\rightarrow[\mathrm{Co}(\mathrm{II})$ - (ARS) $]$ (adsorbed) $\ldots . . .(1)$

\section{Reduction step:-}

[Co(II)- (ARS)] (Adsorbed) $+\mathrm{e}^{-} \rightarrow[\mathrm{Co}(\mathrm{I})-($ ARS $)]$ (Adsorbed)

$[\mathrm{Co}(\mathrm{I})-($ ARS $)]$ (Adsorbed) $+\mathrm{H}^{+} \rightarrow\left[\mathrm{H}^{+}-\mathrm{Co}(\mathrm{I})\right.$ - (ARS) $]$ (adsorbed)

$\left[\mathrm{H}^{+}-\mathrm{Co}(\mathrm{I})-(\right.$ ARS $\left.)\right]$ (adsorbed) $\rightarrow \quad[\mathrm{H}-\mathrm{Co}(\mathrm{II})$ - (ARS) $]$ (adsorbed)

$2\left[\mathrm{H}-\mathrm{Co}(\mathrm{II})\right.$ - (ARS)] (adsorbed) $\rightarrow 2\left[\mathrm{Co}(\mathrm{I})\right.$ - (ARS)] (Adsorbed) $+\mathrm{H}_{2}$

(Stored) 
In the reduction step, the catalytic formation of an adduct between hydrogen and the Co(I)- (ARS) complex by reactions (3), (4) and (5) may combine together to form $\mathrm{H}_{2}$, which is then stored in the space between the electrode surface and the Co(II) - (ARS) layer. In reaction (5), the adsorbed Co(I) - (ARS) complex will continuously carry on the catalytic reaction cycle from reactions (3) to (5). Due to the nature of the catalytic reaction, a trace surface $\mathrm{Co}(\mathrm{II})$ - (ARS) complex can start the whole process and produce a large quantity of $\mathrm{H}_{2}$. In the preconcentration period, the quantity of formed $\mathrm{H}_{2}$ should continuously increase as the catalyst surface quantity increases. After the preconcentration and reduction steps, when the electrode potential is scanned toward a positive direction, the stripping step.

The proposed mechanism is as follows:

$[\mathrm{Co}(\mathrm{I})-(\mathrm{ARS})]$ (adsorbed) $\rightarrow[\mathrm{Co}(\mathrm{II})-($ ARS $)]$ (adsorbed) $+\mathrm{e}^{-}$

$\mathrm{H}_{2}$ (Stored) $+2[\mathrm{Co}(\mathrm{II})-($ ARS $)]$ (adsorbed) $\rightarrow 2[\mathrm{H}-\mathrm{Co}(\mathrm{II})-(\mathrm{ARS})]$ (adsorbed)

$\left[\mathrm{H}-\mathrm{Co}(\mathrm{II})\right.$ - (ARS)] (adsorbed) $\rightarrow\left[\mathrm{H}^{+}-\mathrm{Co}(\mathrm{I})-(\mathrm{ARS})\right]$ (adsorbed)

$\left[\mathrm{H}^{+}-\mathrm{Co}(\mathrm{I})-(\mathrm{ARS})\right]$ (adsorbed) $\rightarrow[\mathrm{Co}(\mathrm{I})-($ ARS $)]$ (adsorbed) $+\mathrm{H}^{+}$

The formed [Co(I)- (ARS)](adsorbed) in reaction (9) would be oxidized back to [Co(II) - (ARS)] (adsorbed)

according to reaction (6), making a continuous catalytic reaction cycle from reactions (6) to (9).

Effect of Supporting Electrolyte, pH:

The influence of supporting electrolyte on peak current response of Co(II) ion with ligand ((ARS)) was examined using different supporting electrolytes such as Potassium Chloride, Sodium nitrate, sodium Perchlorate Acetate buffer, Phosphate buffer and Britton - Robinson Phosphate buffer on the analytical signal was tested. Both the peak height and peak shape were taking into consideration when choosing type of buffer.

Phosphate buffer solution was selected for determination of these trace ions Co(II) with ligand ((ARS)) as optimum conditions. The effect of $\mathrm{pH}$ of Phosphate buffer solution on square wave stripping voltammetry of trace ions $\mathrm{Co}(\mathrm{II})$ metal $2 \times 10^{-6} \mathrm{M}(117.86 \mathrm{ng} / \mathrm{mL})$ in $0.15 \mathrm{M}$ Phosphate buffer at different $\mathrm{pH}$ range (3-11) was studied respectively, as shown in Fig.(2).

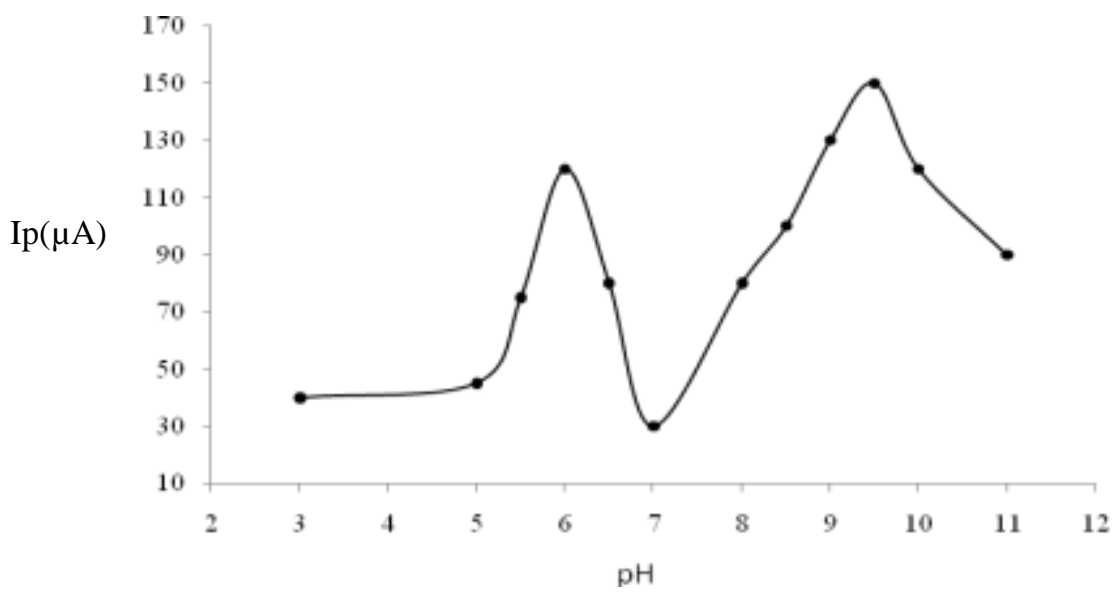

Fig.2:-Plot of Ip versus pH using Phosphate buffer buffer solution in presence of $2 \times 10-6 \mathrm{M}(117.86 \mathrm{ng} / \mathrm{mL}) \mathrm{Co}$ (II) ion at $-0.35 \mathrm{~V}$ accumulation potential and $15 \mathrm{~s}$ accumulation time.

A small current was observed at $(\mathrm{pH}=6)$ which increased gradually up to $\mathrm{pH}=9.5$ which used in all measurements. The cathodic potential of the Co(II)- (ARS) complex is shifted linearly towards less negative values with increasing the $\mathrm{pH}$ over than 9.5 the best medium used for studying the stripping analysis of Co (II) - (ARS) is 0.15M Phosphate buffer $(\mathrm{pH}=9.5)$.

\section{Effect buffer concentration:-}

The influence of buffer concentration of Phosphate buffer of $\mathrm{pH} 9.5$ on the square wave stripping voltammetry of trace ions Co(II) was investigated. The study utilizing $(117.86 \mathrm{ng} / \mathrm{mL}) \mathrm{Co}(\mathrm{II})$ with (ARS) using different ionic 
strength from 0.02- 0.6 M of Phosphate buffer. Figure (3) illustrate the plot of peak current versus buffer concentration, the study raveled that the best medium used for studying the stripping analysis of Co(II) ion is 0.15 M Phosphate buffer ( $\mathrm{pH}=9.5)$.

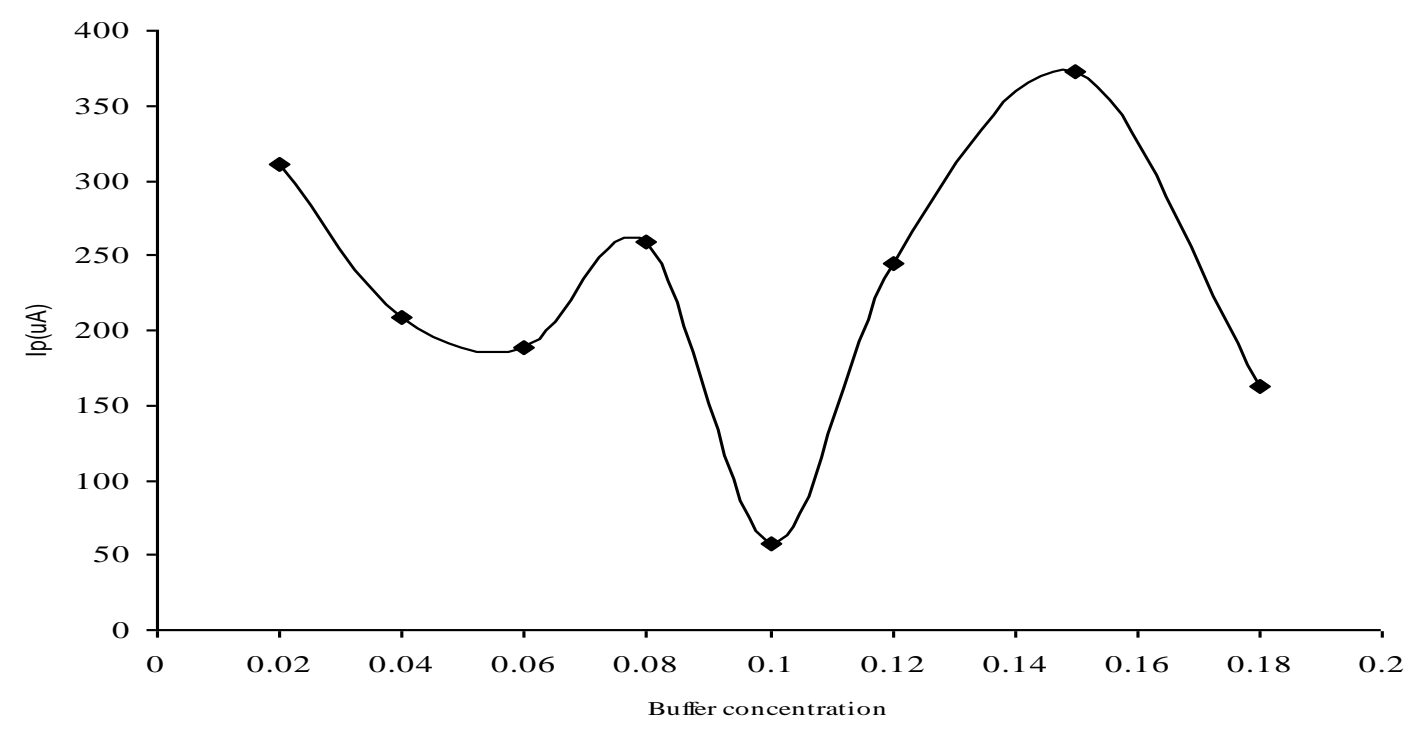

Fig.3:-Plot of Ip versus buffer concentration in presence $117.86 \mathrm{ng} / \mathrm{mL}$ of $\mathrm{Co}(\mathrm{II})$ ion and (ARS) on electrode surface at $(\mathrm{pH}=9.5),.-0.35 \mathrm{~V}$ accumulation potential and $15 \mathrm{~s}$ accumulation time.

\section{Effect of accumulation potential:-}

The effect of accumulation potential on stripping peak current for $2 \times 10^{-6} \mathrm{M}(117.86) \mathrm{Co}(\mathrm{II})$ ion at $\mathrm{pH}=9.5$ was also investigated in potential range from +0.1 to $(-0.6) \mathrm{V}$ at $15 \mathrm{~s}$. The peak current of stripping signal complex increase in the range +0.1 to $(-0.35) \mathrm{V}$ potential and decrease with negative shifting from $(-0.35)$ to $(-0.6) \mathrm{V}$. The peak current has its maximum value at initial potential $(-0.35) \mathrm{V}$, which was used in the subsequent examination of other decencies. Plot of peak current versus initial potential is shown in Fig. (4).

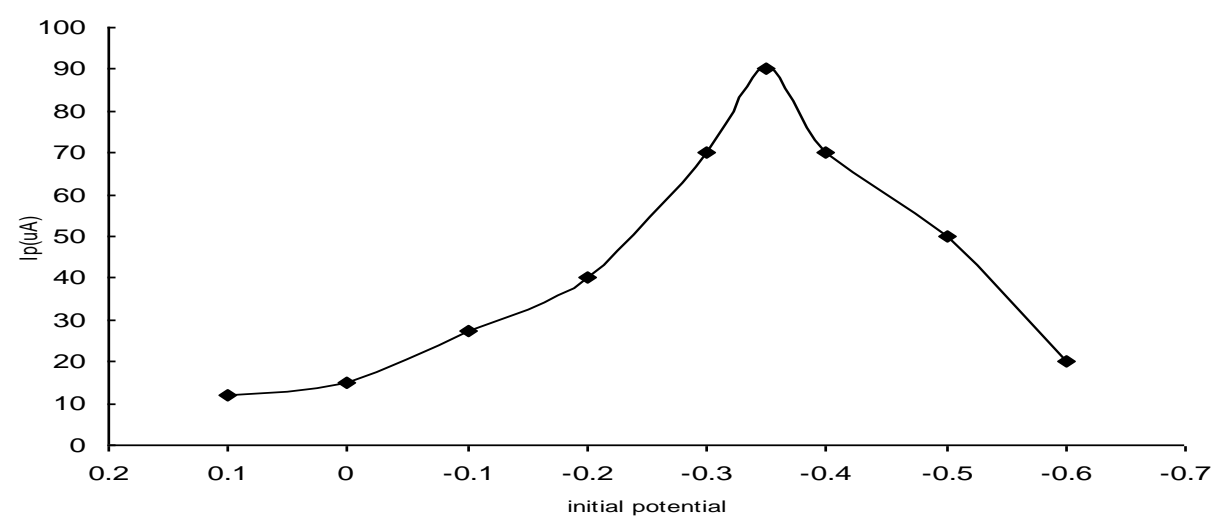

Fig. 4:-Plot of Ip versus different initial potentials (V) in presence of $117.86 \mathrm{ng} / \mathrm{mL}$ of $\mathrm{Co}(\mathrm{II})$ ion at $(\mathrm{pH}=9.5)$.

\section{Effect of Accumulation Time and Reproducibility:-}

The dependence of the peak current an accumulation time was studied for one level of concentration named as $2 \times 10^{-6}(117.86 \mathrm{ng} / \mathrm{mL})$ of $\mathrm{Co}(\mathrm{II})$ at $0.15 \mathrm{M}$ Phosphate buffer $\mathrm{r}(\mathrm{pH}=9.5)$. The stripping signal increased linearly with increase accumulation time up to $176 \mathrm{~s}$ after that occur a decrease in the stripping signal. Figure 5, illustrate plot of the peak current versus different times. 


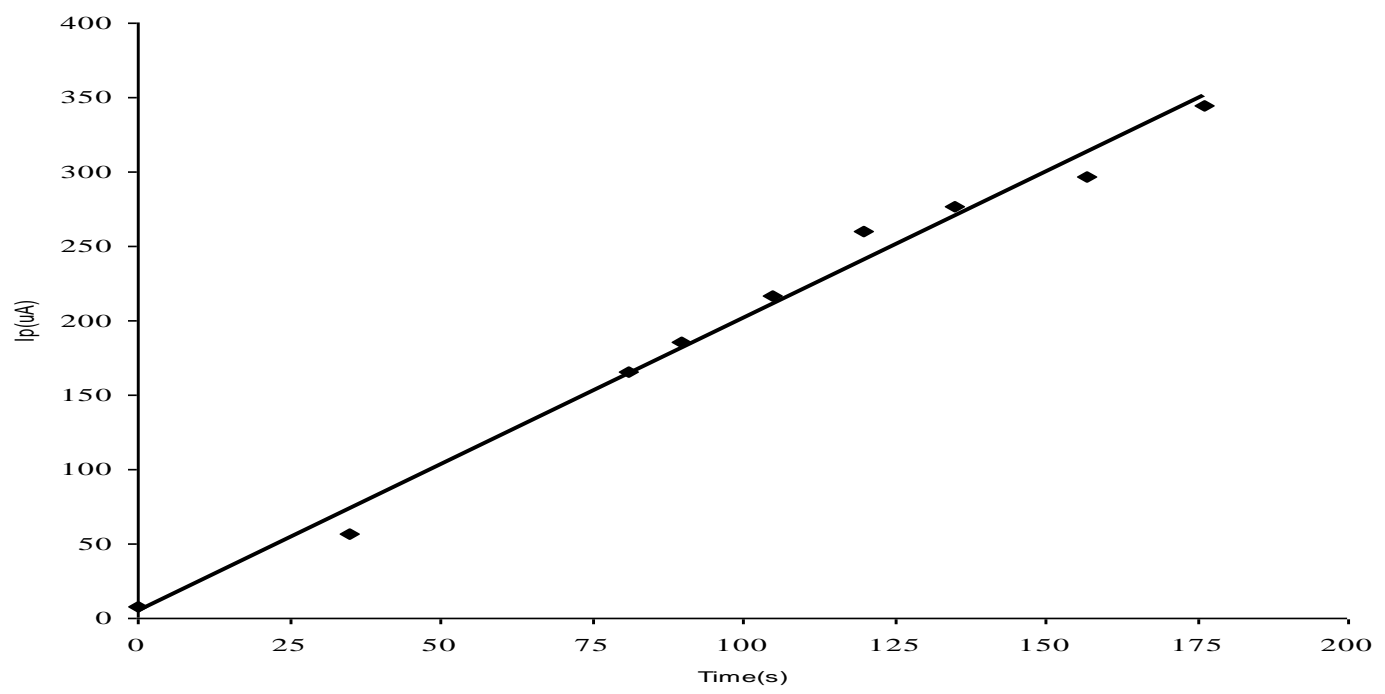

Fig.5:-Plot of the peak current versus different pre-concentration times in presence of $(117.86 \mathrm{ng} / \mathrm{mL})$ of $\mathrm{Co}$ (II) ion at optimum conditions.

\section{Effect of Concentration and detection Limit:-}

The square wave cathodic stripping peak for Co(II) ion with ((ARS)) complex yields a well-defined peak concentration dependence using Square Wave Cathodic Stripping Voltammetry (SWCASV) method. Calibration plot over the Co(II) with (ARS) concentration range was investigated.

The quantitative evaluation is based on the dependence of the peak current on Co (II) concentration. A well-defined peak was observed with the stirring at $(-0.518 \mathrm{~V})$ of Co(II) ion is shown in Fig.6, at 60 s. A linear concentration range was $2 \times 10^{-12}-6 \times 10^{-11} \mathrm{M}(0.00012-0.00354 \mathrm{ng} / \mathrm{mL})$ at $60 \mathrm{~s}$. If the Co(II) ion concentration is higher than 0.035 $\mathrm{ng} / \mathrm{mL}$, a deviation from linearity is observed. The Calibration plot of the peak current versus different concentrations is shown in Fig.7. However, the detection limits estimated as $3 \sigma / b$ [21, 22, 23], where $b$ is the slope and $\sigma=$ standard deviation (SD) of the intercept, quantitative limits was computed as $10 \sigma / \mathrm{b}$. The results obtained from the proposed method show that $\mathrm{Co}$ (II) ion can be detected for $2 \times 10^{-13} \mathrm{M}$ with relative standard deviation \pm $0.01 \%$, Correlation coefficient $\mathrm{r}=0.9996$ for Co (II) $(\mathrm{n}=5)$ at accumulation time $60 \mathrm{~s}$.

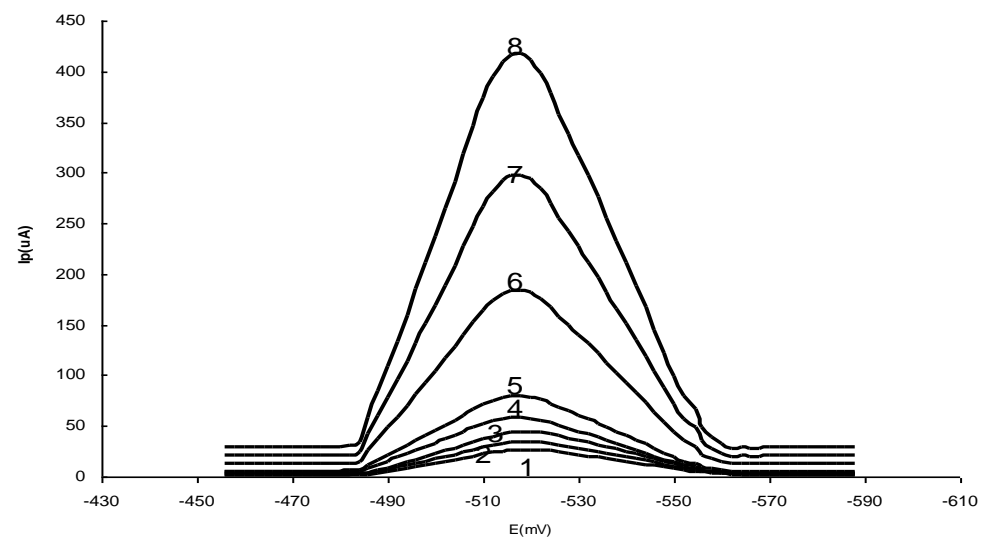

Fig.6:-Typical SWCAS voltammogram of Co(II) ion at different concentrations of Co(II) ion in presence of (ARS) modified electrode, $0.15 \mathrm{M}$ Phosphate buffer $(\mathrm{pH}=9.5), 60 \mathrm{~s}$ accumulation time , and (1): 0.00012 $\mathrm{ng} / \mathrm{mL},(2): 0.00024 \mathrm{ng} / \mathrm{mL},(3): 0.00035 \mathrm{ng} / \mathrm{mL}$, (4): $0.00047 \mathrm{ng} / \mathrm{mL}$, (5): $0.00059 \mathrm{ng} / \mathrm{mL}$, (6): 0.00118 $\mathrm{ng} / \mathrm{ml}$, (7): $0.00236 \mathrm{ng} / \mathrm{ml}$ and (8): $0.00354 \mathrm{ng} / \mathrm{ml}$ of Co(II) ion. 


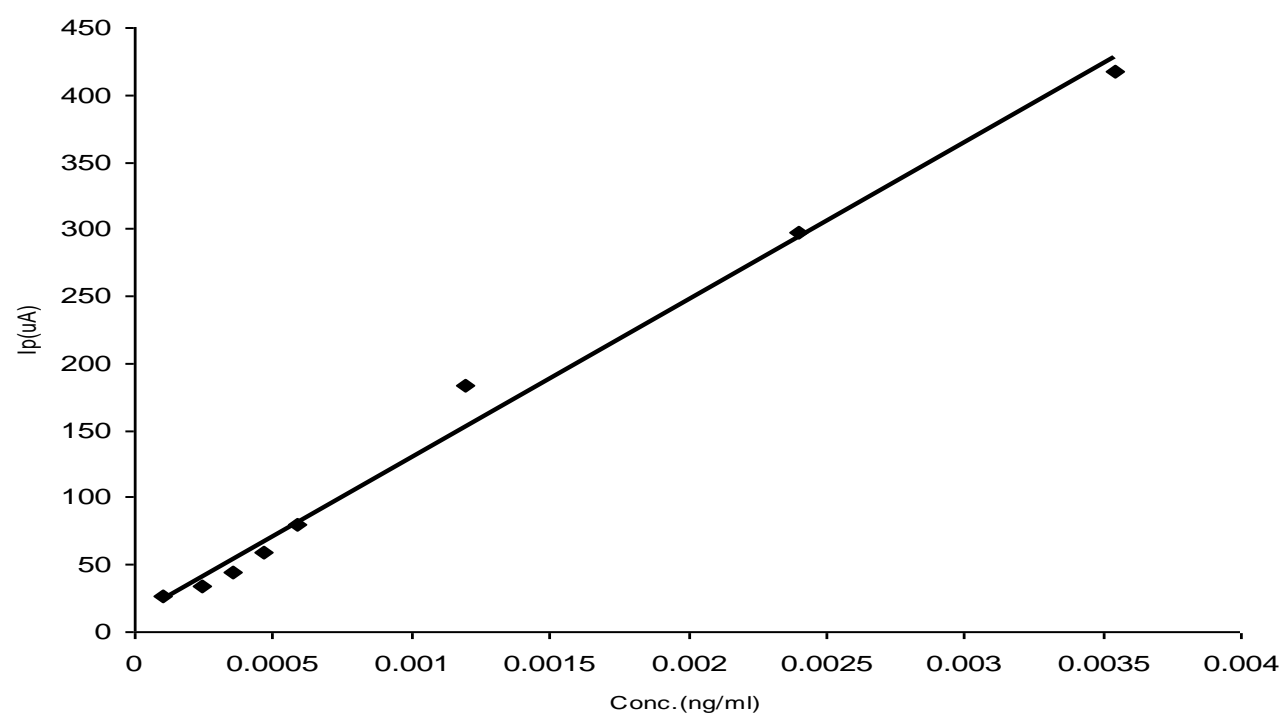

Fig.7:-Plot Ip versus different concentrations of Co(II) ion in presence of (ARS) on electrode surface, $0.15 \mathrm{M}$ Phosphate buffer $(\mathrm{pH}=9.5)$ at $60 \mathrm{~s}$ accumulation time.

\section{Effect of interferences:-}

To investigate the efficiency and selectivity of the proposed analytical method for determination of Co(II) ion with (ARS) complex formulation, a synthetic solution containing a fixed amount trace ion of Co(II) ion $2 \times 10^{-6} \mathrm{M}$ was spiked, excess amount of some common interfering species (10:1) the interfering species Glycine, DL- argnine, DL - Valine (amino cids), Ascorbic acid, Urea, Glucose, $\mathrm{Fe}(\mathrm{III}), \mathrm{pb}(\mathrm{II}), \mathrm{Na}(\mathrm{I})$ and $\mathrm{Cd}$ (II). These interfering species were added to voltammetric cell to study the effect of such interfering species under the optimum experimental conditions.

\section{Effect of some amino acids:-}

Different concentrations Glycine, DL- argnine and DL - Valine ranged $2 \times 10^{-6}-2 \times 10^{-5} \mathrm{M}$ were added to $2 \times 10^{-6} \mathrm{M}$ of Co(II) - ((ARS)) complex then the voltammograms were recorded. The results showed that the addition of $2 \times 10^{-6}-$ $2 \times 10^{-5} \mathrm{M}$ of Glycine, DL- argnine and DL-Valine increase in the current peak by about $12.16-13.63 \%, 61.28$ $79.08 \%$ and $63.49-76.19 \%$ for Glycine, DL- argnine and DL-Valine, respectively.

\section{Effect of Ascorbic acid, urea and Glucose:-}

Also, different concentrations of Ascorbic acid, urea and Glucose ranged from $2 \times 10^{-6}-2 \times 10^{-5} \mathrm{M}$ were added to $2 \times 10^{-6} \mathrm{Co}(\mathrm{II})-((\mathrm{ARS}))$ complex, and then the voltammograms were recorded. The results showed that a significant interference. The addition of $2 \times 10^{-6}-2 \times 10^{-5} \mathrm{M}$ from Ascorbic acid, urea and Glucose to Co(II)-((ARS)) complex, showed the peak current increase by about 10.71-26.5 \% , 12.19-53.04 \% and 10.97-13.04 \% for Ascorbic acid, urea and Glucose, respectively.

\section{Effects of some metal ions:-}

The effect of some metal ions such as $\mathrm{Fe}$ (III), $\mathrm{Pb}$ (II), $\mathrm{Na}$ (I) and $\mathrm{Cd}$ (II) on the peak response of $2 \times 10-{ }^{6} \mathrm{M}$ of $\mathrm{Co}(\mathrm{II})-((\mathrm{ARS}))$ complex were studied. Different concentrations of $\mathrm{Fe}(\mathrm{III}), \mathrm{pb}(\mathrm{II}), \mathrm{Na}(\mathrm{I})$ and $\mathrm{Cd}(\mathrm{II})$ ranged from $2 \times 10^{-6}-2 \times 10^{-5} \mathrm{M}$ were added. In the presence of Fe (III) the current peak response decrease by (-30.58-(- 21.49) \% .In the case of $\mathrm{Pb}$ (II) increase in the current peak by about $23.56-27.48 \%$.

For $\mathrm{Cd}(\mathrm{II})$ and $\mathrm{Na}$ (I) the peak current response increase by about $11.30-31.5 \%$ and $25.43-30.43 \%$, respectively.

\section{Real sample analysis:-}

The developed method was applied to the determination of $\mathrm{Co}$ (II) in natural waters [24-30 ] and human hair. The procedure of wet ashing of human hair is described by Henry et al. [31]. Sample was ashed in silica crucibles in a 
muffle furnace at $450 \mathrm{C}$ for several hours, until a white powder remained, then dissolved in $5 \mathrm{or} 10 \mathrm{ml} 0.1 \mathrm{~N}$ hydrochloric acid and stored in polyethylene bottles. $30 \mu \mathrm{L}$ of this solution was added to $15 \mathrm{~mL} 0.15 \mathrm{M}$ Phosphate buffer with $\mathrm{pH} 9.5$, and the general procedure was used on the resultant solution. For natural waters, these samples were taken instead of distilled water used for the preparation of Phosphate buffer ( $\mathrm{pH} 9.5)$, and the general procedure was used on these resultant solutions. The standard addition method was applied for the determinations of cobalt ions. The results obtained by the proposed method were compared with ICP method. The results were summarized in Table (2). Statistical comparison at the 95\% confidence level showed no significant difference between the results obtained with the proposed procedure and those of the ICP standard method.

Table 2:-The determination of Co(II) in water and human hair samples.

\begin{tabular}{|l|l|l|l|c|c|c|}
\hline \multicolumn{1}{|c|}{ Sample } & $\begin{array}{l}\text { Present } \\
\text { method, } \\
\text { ng/mL or } \\
\mu g / g \text { for hair }\end{array}$ & $\begin{array}{c}\text { ICP method, } \\
\text { ng/mL or } \\
\mu g / g \text { for hair }\end{array}$ & $\begin{array}{c}\text { Recovery } \\
\text { of ICP, } \\
\%\end{array}$ & $\begin{array}{c}\text { Spiked } \\
\text { Co }^{2+} \\
\text { ng/mL }\end{array}$ & $\begin{array}{c}\text { Found Co } \\
\text { ng/mL }\end{array}$ & $\begin{array}{c}\text { Recovery } \\
\text { of ICP, \% }\end{array}$ \\
\hline Red sea water & $0.15 \pm 0.04$ & $0.16 \pm 0.06$ & 93.33 & 100 & $99.84 \pm 1,53$ & 99.76 \\
\hline River water & $0.032 \pm 0.15$ & $0.035 \pm 0.04$ & 91.48 & 100 & $103 \pm 0.08$ & 99.83 \\
\hline Human hair & $0.17 \pm 0.025$ & $0.18 \pm 0.07$ & 96,71 & - & - & - \\
\hline
\end{tabular}

\section{Conclusion:}

This paper showed that the (ARS) is a useful ligand for the highly sensitive and selective determination of Co(II) by adsorptive stripping voltammetry at CPE. The cheap and nonpoisonous CPE was used instead of the severe toxic, expensive mercury electrodes in this method. Thus, it has excellent environmental and economical benefit. This method showed high selectivity and reproducibility. The procedure presented in this study could be used for the determination of cobalt in water and human hair samples with good accuracy and precision.

\section{References:-}

1. Wang J., Analytical Electrochemistry, 2nd edn, Wiley-Vch, New York, 2000.

2. Bobrowski, A., Zarebbski, J., (2000) Catalytic Systems in Adsorptive Stripping Voltammetry. Electroanalysis 12 (15), 1177-1186.

3. Gao Z. Siong Siow, K. , (1996) Catalytic-adsorptive stripping voltammetry of cobalt in the presence of 2,2'bipyridine and nitrite. Talanta 43: 255-261.

4. Vega M., van den Berg C.M.G (1997) Determination of Cobalt in Seawater by Catalytic Adsorptive Cathodic Stripping Voltammetry

5. Anal. Chem 69: 874-881.

6. Safavi, A., Shams, E (2000) Highly sensitive and selective measurements of cobalt by catalytic adsorptive cathodic stripping voltammetry. Talanta, 51:1117 -1123

7. Bobrowski, A., Bond, A.M (1991) Catalytic adsorptive stripping voltammetric determination of cobalt as an $\alpha$-benzil dioxime complex in the presence of an extremely large excess of zinc. Electroanalysis 3: 157-162.

8. Donat, J.R., Bruland K. W (1988) Direct determination of dissolved cobalt and nickel in seawater by differential pulse cathodic stripping voltammetry preceded by adsorptive collection of cyclohexane-1,2-dione dioxime complexes Anal. Chem. 60:240-244.

9. Wang J., Analytical Electrochemistry (2nd Edition), VCH Publishers, inc., New York (1994) 44 -54.

10. Brainina K. H. and Neyman E., Electroanalytical Stripping Methods, John Wiley and Sons, New York '1; (1993) 71-120.

11. Wang J., Stripping Analysis: Principles, Instrumentation and applications, VCH Publishers Inc., Florida, 1985.

12. Kalvoda R., Adsorptive Stripping Voltammetry in Analytical Chemistry II, (J. Zuka, Ed.), Ellis Horwood, New York, 1996.

13. Wang J., Electroanalytical Techniques in Clinical Chemistry and Laboratory Medicine, VCH Publishers Inc., New York, (1988) 17-20.

14. Zaitsev P. M., Salikhdzhanova R. M. and Zaitsev N. K., Indus. Lab Diagno. Mater., 65, (1999), 1-15.

15. Abu Zuhri A. Z. and Voelter W (1998) Applications of adsorptive stripping voltammetry for the trace analysis of metals pharmaceuticals and biomolecules Fresenius J. Anal. Chem 360 1-9.

16. Brainina K. H., Malakhova N. A. and Stojko N. Y (2000) Stripping voltammetry in environmental and food analysis Fresenius J. Anal. Chem 368 307-25.

17. Alghamdi A. H., areview, J. Saudi Chem Soc., 6, (2002), 185-98. 
18. Vire J. C., Kauffmann J. M. and Patriarche G. J (1989), Adsorptive stripping voltammetry applied to drug analysis: a powerful tool.

19. J. Pharma. Biomed. Anal7:1323-35.

20. Farghaly O.A (2004) a novel method for determination of magnesium in urine and water samples with mercury film-plated carbon paste electrode. Talanta 63 497-501.

21. Amrallah A.H., Abdalla N.A. and El-Haty (1998) Mixed ligand complexes of benzimidazole and pyrimidine hydroxy azo dyes with some transition metals and glycine, dl-alanine or dl-leucine.Talanta, 46 (4) 491-500.

22. Cassandra R. B. C., Aldaléa L. B.M., Edmar P. M., William S.C. and Jiujun Zhang (2006) Ultra Trace Copper Determination by Catalytic-AdsorptiveStripping Voltammetry Using an Alizarin Red S modified Graphite Electrode Int. J.Electrochem. Sci 1, 343-353

23. O. A. Farghaly (2003) Direct and simultaneous voltammetric analysis of heavy metals in tap water samples at Assiut city: an approach to improve the analysis time for nickel and cobalt determination at mercury film electrode Microchemical Journal 75 119-131.

24. [22]- Ali A. M., Farghaly O. A. and Ghandour M. A (2000) Determination of thiopentone sodium in aqueous and biological media by cathodic stripping voltammetry Anal.Chim. Acta 412 99-110.

25. Farghaly O. A., Abd El-Wadood H. M. and Ghandour M. A (1999) Anodic adsorptive stripping voltammetric determination of the anesthetic drug: methohexital sodium J. Pharm. Biomed. Anal 21 233-240.

26. Gelaneh Woldemichael a,Taffa Tulu b , Gerd-Uwe Flechsig (2016) Solar UV-treatment of water samples for stripping-voltammetric determination of trace heavy metals in Awash river, Ethiopia

27. Heliyon 2(3) e00091

28. Iwona Rutyna, Mieczyslaw Korolczuk (2015) Determination of cobalt by adsorptive stripping voltammetry with double accumulation and stripping steps International Journal of Environmental Analytical Chemistry 95(11) 1042-1053

29. [26]- Foroozan H.,Hossein T., Masoud F. and Masoumeh (2013)

30. Trace and selective determination of cobalt(II) in water and salt samples using cathodic adsorptive stripping voltammetry in the presence of Pyrogallol Red J. Serb. Chem. Soc. 78 (5) 717-724

31. Carlos R., Verónica A., Marisol G. and Edgar N (2012) Adsorptive Stripping Voltammetric Determination of Cobalt in the Presence of Nickel and Zinc Using Pyrogallol Red as Chelating Agent Int. J. Electrochem. Sci. 7: 979 - 990

32. A.Mohadesi, E. Teimoori, M. Taher and H. Beitollah (2011) Adsorptive Stripping Voltammetric Determination of Cobalt (II) on the Carbon Paste Electrode International Journal Electrochem Science 6(2) 301308.

33. S. Bahrami, S. Abbasi, Y. A. Ghorbani and A. A. Miran-Beigi (2009) High sensitive determination of trace amount of cobalt by catalytic adsorptive stripping voltammetry Russian J. Electrochem 45(2) 208- 214.

34. Zhang Hao , J-C. Vire, G. J. Patriarche \& R. Wollast (1988) Determination of Cobalt Ions in Natural Waters Using Differential Pulse Adsorptive Stripping Voltammetry Analytical Letters, 21( 8) 1409 - 1424

35. Henry A. Schroeder M. DAlexis P. Nason B.A (1969) Trace Metals in Human Hair Journal of Investigative Dermatology 53(1) 71-78. 